\title{
Effect of Conifer Encroachment Into Aspen Stands on Understory Biomass
}

\author{
B. R. Stam, ${ }^{1}$ J. C. Malechek, ${ }^{2}$ D. L. Bartos, ${ }^{3}$ J. E. Bowns, ${ }^{4}$ and E. B. Godfrey ${ }^{2}$ \\ Authors are ${ }^{1}$ Assistant Extension Educator, University of Wyoming Cooperative Extension Service, Thermopolis, WY 82443, USA; ${ }^{2}$ Professor, Utah State \\ University, Logan, UT 84322-5320, USA; ${ }^{3}$ Ecologist, US Department of Agriculture, Forest Service, Rocky Mountain Research Station, Logan, UT \\ 84321, USA; and ${ }^{4}$ Professor, Southern Utah University, Cedar City, UT 84720, USA.
}

\begin{abstract}
Conifers (Picea and Abies spp.) have replaced aspen (Populus tremuloides Michx.) over much of aspen's historic range in the western United States. We measured the impact of this change upon the production of understory vegetation potentially useful as forage for livestock and wildlife on two southern Utah national forests. A negative exponential relationship between conifer cover and understory biomass was demonstrated as $\log$ (biomass) $=6.25-0.03787$ ( $\%$ conifer), adjusted $R^{2}=0.57$. Understory production in aspen stands begins to decline under very low levels (10\% to $20 \%)$ of conifer encroachment. Management implications include loss of forage production capability and wildlife habitat and potential overstocking of livestock grazing allotments if the associated loss of forage is not considered.
\end{abstract}

\section{Resumen}

Las confieras (Picea y Abies spp.) han remplazado al álamo (Populus tremuloides Michx.) en gran parte del rango histórico de distribución de esta especie en el oeste de los Estados Unidos de América. Medimos el impacto de este cambio sobre la producción del estrato herbáceo potencialmente útil como forraje para el ganado y fauna silvestre en dos bosques nacionales del sur de Utah. Se demostró una relación exponencial negativa entre la cobertura de coníferas y la biomasa del estrato herbáceo, tal como lo demostró la siguiente ecuación: $\log ($ biomasa $)=6.25-0.0378(\%$ conífera $), R^{2}$ ajustada $=0.57$. La producción herbácea en las poblaciones de álamo inicia a disminuir a muy bajos niveles $(10 \%$ a $20 \%)$ de expansión de las coníferas. Las implicaciones de manejo incluyen pérdida de capacidad de producción de forraje y del hábitat para la fauna silvestre y una sobrecarga potencial de ganado, si la pérdida de forraje asociadas no se considera.

Key Words: canopy, Dixie National Forest, Fishlake National Forest, forage, Populus tremuloides

\section{INTRODUCTION}

Across eight of the western states (Arizona, Idaho, Utah, Wyoming, Colorado, Nevada, New Mexico, and Montana) quaking aspen (Populus tremuloides Michx.) stands now occupy only about $40 \%$ of their estimated historic range (Bartos 2001), having been replaced by coniferous species, mainly Picea and Abies spp. Over much of this region, including the area where this study was conducted, aspen is considered a seral species in a conifer climax (Mueggler 1988). However, aspen forest habitat types where aspen is thought to be the climax species have also been observed in the region. What determines whether aspen is succeeded by conifers or remains the climax dominant is still unclear (Mueggler 1988).

A major reduction in anthropogenic burning and increased effectiveness of wildfire control since European settlement are thought to be major contributors to the changes in forest cover (Mueggler 1988). Aspens are among the first species to recolonize an area after a disturbance such as fire. In the absence of subsequent disturbances and with an available seed source, coniferous species frequently establish, outcompete the aspens, and, in time, dominate the site.

This research was supported by the Utah Agricultural Experiment Station, Utah State University, Logan, Utah. Approved as journal no. 7891

At the time of the research, Stam was Graduate Research Assistant, Dept of Forest, Range and Wildlife Sciences, Utah State University, Logan, UT, USA.

Correspondence: B. R. Stam, University of Wyoming Cooperative Extension Service, 328 Arapahoe, Thermopolis, WY 82443, USA. Email: brstam@uwyo.edu

Manuscript received 17 November 2006; manuscript accepted 16 October 2007.
A number of resource values and attributes are generally considered to be lost or forgone as a result of this successional change, including a decline in water yields from mountain watersheds and a reduction in biodiversity (DeByle 1985; Bartos and Campbell 1998). Intact aspen stands are also among the most prolific producers of livestock and native ungulate forage (grasses, forbs, shrubs, and young aspens) in the Intermountain West. Aspen stands also provide excellent habitat for many small mammal and avian wildlife species (Bartos 2001).

Previous research indicates that a coniferous component in the canopy of a forest cover type typically has a predictably strong negative impact on understory biomass production (Jameson 1967); however, an aspen canopy per se appears to have no consistent effect (Betters 1983). This probably relates to the very different physical structure and physiological properties associated with deciduous aspen compared to evergreen conifers. The fundamental hypothesis of this study is that understory biomass production varies as a function of the amount of conifers in the canopy, and our prime objective was to quantify this relationship as it relates to the mixed aspen-conifer forest cover type of southern Utah.

\section{METHODS}

\section{Study Area}

Sample sites were located on the Cedar City Ranger District of the Dixie National Forest, the Richfield Ranger District of the Fishlake National Forest, and privately owned land on Cedar 
Mountain, approximately $20 \mathrm{~km}$ east of Cedar City, Utah. Sites ranged in elevation from 2618 to $3035 \mathrm{~m}$ (mean of $2815 \mathrm{~m}$ ). Total precipitation at the Webster Flat meteorological station, approximately $10 \mathrm{~km}$ from the sites sampled both years, was $3.66 \mathrm{~m}$ for 2002, compared to $5.87 \mathrm{~m}$ for 2003 (Utah Snotel 2003). However, both years were well below the 23 -yr average of $7.82 \mathrm{~m}$. About two-thirds of the precipitation at these elevations comes as winter snow and the remaining one-third as monsoonal summer thunderstorms.

The vegetation is characterized by large mountain meadows interspersed among stands of aspen, conifers (Picea engelmannii Parry and Abies concolor [Gord. \& Glend.] Lindl. and Abies lasiocarpa [Hook.] Nutt.), and mixed aspen-conifer cover types. Soils are generally derived from sedimentary limestone parent materials. Typical understory species include the graminoids Bromus carinatus Hooker \& Arn., Agropyron trachycaulum (Link) Malte., Elymus glaucus Buckley, and Carex rossii F. Boott. Common forbs include Delphinium occidentale (S. Wats) S. Wats, Stellaria jamesiana Torr., Achillea millefolium L., Lathyrus spp., Vicia americana Muhl., and Taraxacum officinale Wiggers. Shrubs include Symphoricarpos oreophilus Gray, Rosa woodsii Lindl, Artemisia tridentata Nutt., and Juniperus communis L.

\section{Vegetation Sampling}

Twenty-seven sites distributed over 13 aspen community types (Mueggler 1988) were selected for sampling to gain a perspective of how the presence of conifers in the stand influences the community's ability to produce understory biomass. The 13 community types were chosen to represent both the high and low ends of the understory production spectrum for southern Utah aspen communities, based on Mueggler's (1988) publication. Sites with a component of tall forbs (i.e., D. occidentale) were placed into the "high" category. Those sites with low forbs (i.e. S. jamesiana, A. millefolium, Lathyrus spp., V. americana, and T. officinale received a "low" classification. Characteristics such as elevation, aspect, and soil types were considered when designating sites as having high or low potential. According to Mueggler (1988), biomass production could be expected to vary widely across these community types, ranging from as little as 11 to as much as $4260 \mathrm{~kg} \cdot \mathrm{ha}^{-1}$. An additional key criterion in sample site selection was the presence of stands still dominated by aspen close (i.e., on the same soil type, slope, and elevation) to adjacent stands with varying levels of conifer encroachment. Sites were selected that presented the widest possible range of conifer presence, within the criteria specified above. In the absence of fire or other major perturbations, aspen replacement by conifers is the common successional trajectory for these communities. According to Mueggler's (1988) community type key, when the conifer component of an aspen stand exceeds $10 \%$, the community type designation changes. Therefore, we sampled stands with a major contemporary conifer component that once probably would have been classified as the same community type as those nearby currently having few or no conifers.

At each sample site, a center point for transects was randomly chosen and permanently marked by a steel fencepost. Four 30-m transect lines were then established radiating from this center post in the four cardinal directions. Transect lines were demarcated by the use of a tightly stretched fiberglass surveyor's tape.

A $1.0-\mathrm{m}^{2}$ square, three-sided quadrat frame was placed at 7.62-m intervals along the right side of each transect, yielding 16 quadrat placements per site (four per transect). Herbaceous biomass in each quadrat was estimated by the weight estimate technique (Pechanec and Pickford 1937). Biomass of shrubs was estimated by use of the reference unit method (Kirmse and Norton 1985). Shrubs were sampled only if they were rooted within the quadrat.

Species composition and canopy coverage of the tree overstory was measured at each site. Canopy cover was measured from the ground through a modification of the line-point intercept technique (Cook and Stubbendieck 1986). Cover readings were taken at $1-\mathrm{m}$ intervals along each transect, looking upward through a periscope device (termed "canopyometer") that was a modification of the one described by Morrison and Yarranton (1970). This device consisted of a 2-m staff with a rifle scope attached near the top. A small mirror was attached below the scope's ocular lens. By placing the canopyometer vertically at each transect interval, the observer could view the canopy by looking in the mirror. The crosshairs in the scope allowed the observer to pinpoint the canopy cover reading. Thirty such points were observed on each transect, yielding 120 points per site. Data were then summarized and analyzed as absolute canopy cover, by species. For example, if 30 points on a particular transect were intercepted by aspen canopy and 60 by a conifer species, out of 120 points total, that would be reported as $25 \%$ aspen and $50 \%$ conifer cover. Multiple strata of cover were not considered. Sites were sampled once each year soon after graminoid species had attained peak biomass judged visually by the presence of mature seed heads. Sites that were sampled in both 2002 and 2003 were sampled within $1 \mathrm{wk}$ of the same date. Because sites are within highelevation, summer-use grazing allotments, peak biomass was attained before exposure to livestock grazing during a particular year. This allowed vegetation sampling before livestock utilization of the forage. Significant biomass removal by native herbivores was not apparent at any study site.

In addition to these measurements, the following information was recorded at each site: aspect, elevation, and location of the permanent marker post in Universal Transverse Mercator units, using a surveyor's compass and a global positioning system receiver. These supplementary data are presented in Stam (2004).

The field research took place during the summers of 2002 and 2003. Eleven sites were sampled in 2002. In 2003, these sites were resampled (to assess year-to-year variation), plus 16 additional sites, yielding a sample size of 27 for data taken in 2003.

\section{Statistical Analyses}

The completely randomized analysis of covariance design (sites within potential, percentage of conifer canopy coverage as a covariate) was analyzed using SAS PROC GLM (SAS Institute Inc 1999). Biomass data were log transformed to correct for homoscedastic variance across levels of percentage of conifer.

In accordance with standard analysis of covariance procedures (Milliken and Johnson 2002), several models for 
Table 1. Understory biomass, conifer cover, and aspen cover in 2002 and 2003.

\begin{tabular}{|c|c|c|c|c|c|c|}
\hline \multirow[b]{2}{*}{ Study site } & \multicolumn{2}{|c|}{ Understory biomass $\left(\mathrm{kg} \cdot \mathrm{ha}^{-1}\right)$} & \multicolumn{2}{|c|}{ Conifer cover (\%) } & \multicolumn{2}{|c|}{ Aspen cover (\%) } \\
\hline & 2002 & 2003 & 2002 & 2003 & 2002 & 2003 \\
\hline Miner's Peak & 954 & 1482 & 0 & 0 & 62 & 58 \\
\hline Crystal no. 1 & 637 & 1208 & 4 & 5 & 63 & 62 \\
\hline Crystal Powerline & 227 & 298 & 19 & 23 & 33 & 37 \\
\hline Crystal no. 2 & 182 & 337 & 50 & 52 & 30 & 29 \\
\hline Crystal no. 3 & 45 & 85 & 76 & 75 & 5 & 8 \\
\hline Jim's no. 1 & 227 & 198 & 1 & 4 & 53 & unavailable \\
\hline Dark Hollow ${ }^{1}$ & 186 & 268 & 0 & 0 & 93 & 95 \\
\hline Strips $A^{1}$ & 186 & 222 & 0 & 0 & 28 & 30 \\
\hline Seth's Site ${ }^{1}$ & 182 & 173 & 0 & 0 & 75 & 66 \\
\hline Strips B & 77 & 84 & 35 & 36 & 2 & 3 \\
\hline Jim’s no. 2 & 9 & 10 & 59 & 60 & 9 & 19 \\
\hline Mean/standard error & $264.73 / 84.8^{2}$ & $396.82 / 145.6$ & $22.18 / 8.5^{2}$ & $23.18 / 8.5$ & $41.18 / 9.1$ & $40.7 / 9.2$ \\
\hline
\end{tabular}

${ }^{1}$ Sites have such similar characteristics that data points for these sites are indistinguishable from one another in Figure 1.

${ }^{2}$ Means are significantly different $(P \leq 0.05)$.

$\log$ (biomass) were considered. The first model fitted separate slopes and intercepts for $\log$ (biomass) on percentage of conifer for low- and high-potential sites. If slopes for low- and highpotential sites were significantly different then the analysis stopped with the conclusion that the relationship between $\log$ (biomass) and percentage of conifer depended on the site potential (high or low). If the slopes were not significantly different, the data were pooled for further analysis. If the pooled or common slope was not significantly different from zero, the model was reduced to an analysis of variance for testing the equality of high- and low-potential site (unadjusted) means. If the common slope was significantly different from zero, then the adjusted potential means (or, equivalently, the intercepts) were tested for equality. If there was no difference between the intercepts, the model was simplified to a simple linear regression of $\log$ (biomass) on percentage of conifer.

\section{RESULTS AND DISCUSSION}

\section{Influence of Tree Cover}

Conifer cover affected understory biomass in a major way. Using 2003 data as an example, values ranged from a high of $1482 \mathrm{~kg} \cdot \mathrm{ha}^{-1}$ at $0 \%$ conifer cover to a low of $10 \mathrm{~kg} \cdot \mathrm{ha}^{-1}$ at $60 \%$ conifer cover (Table 1 ). Mueggler (1988) reported that some especially productive aspen sites are capable of yielding up to $4260 \mathrm{~kg} \cdot \mathrm{ha}^{-1}$ of air-dried understory biomass annually. However, this production can reportedly be reduced by $50 \%$ when conifers make up as little as $15 \%$ of the total tree basal area on the site (Mueggler 1985, 1988).

When we expressed understory biomass as a function of conifer overstory, considering both high- and low-potential sites, a negative exponential relationship of the form $\log$ (biomass $)=6.25-0.03787(\%$ conifer $)$ was revealed (Figs. 1 and 2 ). This equation has a $P$ value for slope of $<0.0001$, an adjusted $R^{2}$ of 0.56 and root mean square error of 0.5668 . The slope in this homogeneous model differs significantly $(P<0.0001)$ from zero and the $P$ value for testing normality of residuals from this model is 0.2335 . In the initial fitting of separate models to data from high- and low-potential sites, neither slopes $(P=0.7659)$ nor intercepts $(P=0.1626)$ differed significantly from each other. Consequently, the final homogeneous model was simplified to the expression given above.

The influence of tree canopy on understory biomass production is well documented for several other western forest vegetation types (e.g., Betters 1983, Ffolliott 1983). For example, studies involving ponderosa pine (Pinus ponderosa Lawson), pinyon-juniper (Juniperus spp. and Pinus edulis Engelm. and Pinus monophylla Torr. \& Frem.), and sprucefir (Picea spp. and Abies spp.) have consistently shown that as tree canopy increases, understory plant production decreases in predictable ways. Although various, often complex, models have been developed to describe this relationship (e.g., Jameson 1967), Ffolliott (1983) asserted that the simpler negative exponential form $\mathrm{Y}=\mathrm{a}+\mathrm{be}^{-c x}$ is suitable for nearly all overstory-understory relationships. Our findings support this assertion.

The wide variation in understory production of aspen stands that contained $\leq 5 \%$ conifer cover (Figs. 1 and 2; Table 1 ) was probably a reflection of the high diversity of ecological site properties (elevation, aspect, soil types, moisture relationships) associated with these stands. Again using 2003 data as an example, levels ranged from 173 to $1482 \mathrm{~kg} \cdot \mathrm{ha}^{-1}$ on the six stands, which contained $0 \%$ to $5 \%$ conifer (Table 1 ). Plotting of these six data points (aspen cover vs. understory biomass) indicated no relationship, so these data were not formally analyzed. However, when conifers were present (the extent of the conifer cover was not specified) understory forage production was reduced to less than $111 \mathrm{~kg} \cdot \mathrm{ha}^{-1}$, compared to $1568 \mathrm{~kg} \cdot \mathrm{ha}^{-1}$ in a comparable conifer-free aspen stand. The overwhelming influence of conifer cover is probably also the reason why we were unable to show statistical differences between high- and low-potential sites. Where conifers are present in sufficient abundance to provide cover values of $10 \%$ to $15 \%$ or more, their influence appears to overshadow such site quality factors as soil depth, texture, slope, etc. However, when conifers are not present, site factors are apparently a stronger influence on understory biomass than is aspen 


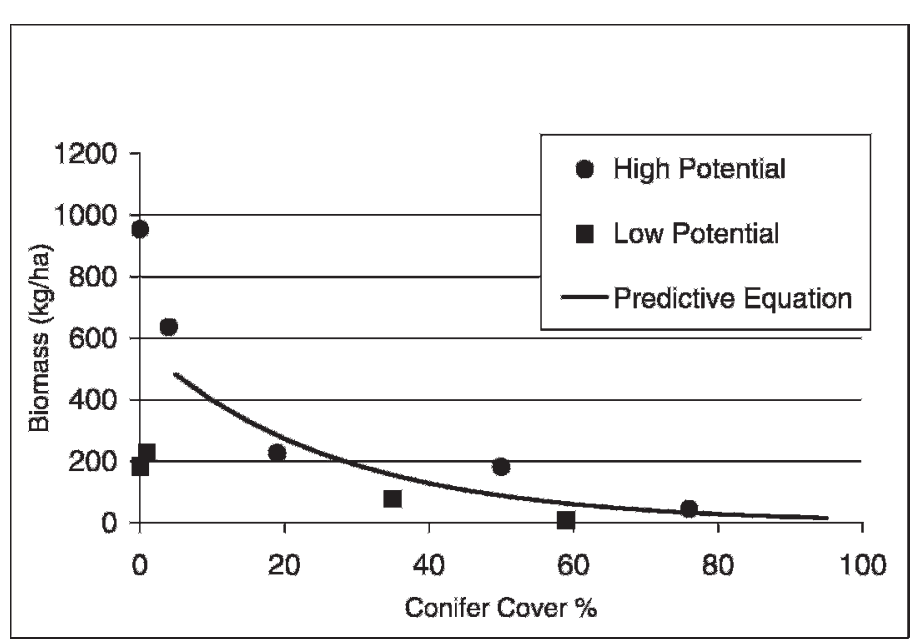

Figure 1. Relationship between conifer canopy cover and herbaceous understory production on high- and low-potential sites, 2002 data. Sites with conifer cover values of zero were pure aspen stands whereas those with conifer cover values of greater than zero are mixed aspen-conifer. The graph is in standard (nonlog) format for ease of interpretation. Note: Three of the sample sites are indistinguishable from one another because of similar site characteristics. These sites are footnoted in Table 1.

canopy cover. Warner and Harper (1972) reported a correlation between site quality factors (soil depth, precipitation, and aspect) and understory production in aspen stands. Aspen is a widely distributed tree species that can thrive on a diversity of sites. Indeed, Mueggler (1988) classified 35 aspen community types for the intermountain region alone, based on understory characteristics and that contain little, if any, conifer component. His work (as well as results of the present study) points to the site's potential for producing either high-biomass understories composed mainly of tall forbs or low-biomass understories dominated by low forbs and graminoids, as the determining factor, not a relationship with tree canopy cover, as is the case with conifers.

Conifers may influence understory production in several ways. One possibility is competition for soil moisture. Interception of precipitation before it reaches the soil plays a role in this regard. When snow falls on a stand with conifers, much of it is intercepted by branches and needles. Much of this then sublimates into the atmosphere and is effectively lost from the system (Fisher and Binkley 2000). Water loss from the longer periods of (year-round) evapotranspiration by conifers (in contrast to only growing-season loss from deciduous aspen) also contributes to making less soil moisture available for understory plant growth (Bartos and Campbell 1998). Conifer canopies are also highly effective at shading understory species, affecting both the quality and quantity of light available for photosynthesis. This is less the case in pure aspen stands where sunlight is better able to penetrate the canopy. The tendency of aspen leaves to move with any slight breeze or "quake" as implied by the common name "quaking aspen" facilitates light penetration (Lambers et al. 1998). Pyke and Zamora (1982) concluded that solar radiation was probably the limiting factor to understory production in mixed conifer stands in northcentral Idaho.

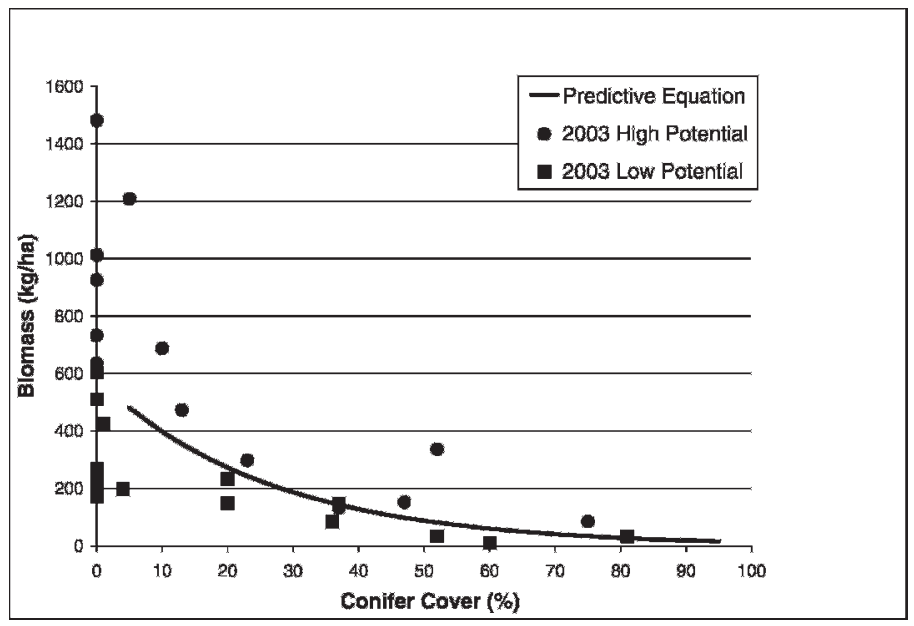

Figure 2. Relationship between conifer canopy cover and herbaceous understory production on high- and low-potential sites, 2003 data. Sites with conifer cover values of zero were pure aspen stands whereas those with conifer cover values of greater than zero are mixed aspen-conifer. The graph is in standard (nonlog) format for ease of interpretation.

\section{Year Effects}

Mean conifer cover increased slightly but significantly $(P \leq 0.05)$ from 2002 to 2003 on the 11 sites that were sampled both years (Table 1). Likewise, the mean understory biomass production increased significantly $(P \leq 0.05)$ from 2002 to 2003. There was no difference in aspen cover from 2002 to 2003 (Table 1). Much of these increases can be attributed to higher amounts of precipitation in 2003 than in 2002. As mentioned above, both years were below average; however, total annual precipitation in 2003 was 2.21 m higher than in 2002. This increase in precipitation was assumed to be key in the observed increase of forage production from 2002 to 2003.

\section{IMPLICATIONS}

Conifers clearly suppress understory biomass production and can do so at relatively small $(10 \%-20 \%)$ percentages of canopy cover. In order to realize the characteristically high forageproducing potential of historic aspen sites, the aspen trees themselves must remain dominant in the stand (Bartos and Campbell 1998). Ohms (2003) showed that decadent aspen stands are capable of regenerating if subjected to such disturbances as partial cuts or fire. Disturbance, either human-induced or by natural processes, may be necessary to revitalize conifer-impacted aspen stands and recover some of the lost forage producing capabilities. This is not to suggest a widespread removal of conifer stands, because conifers provide protective cover, shade, habitat, and commercial products for wildlife, livestock, and humans. Rather, a mosaic of conifer and aspen cover should be considered, the relative quantities of each type being dependent on the management goals of a particular area.

A decline in available forage as a result of conifer encroachment is a major management implication throughout the region where this study was conducted. Most of this area includes grazing allotments. Revisions of livestock stocking rate 
calculations have typically not taken into account the loss of forage production potential due to this successional change. Additionally, many of these areas have sustained large increases in elk (Cervus canadensis L.) populations over the past $20 \mathrm{yr}$. Combined, these factors suggest the possibility of overstocking on some allotments. A more recent phenomenon occurring in the area of this study is the widespread loss of coniferous species to spruce bark beetles (Dendroctonus rufipennis Kirby). Numerous areas (especially in the region of this study) have experienced near total losses of mature spruce trees. Included are sites thought to have been historic aspen types that were subsequently succeeded by coniferous species. The long-term results of this perturbation on aspen recolonization and understory forage production remain to be seen.

\section{ACKNOWLEDGMENTS}

Authors wish to thank Dr David Turner, US Department of Agriculture (USDA) Forest Service, for assistance in statistical analysis. Mr Robert Campbell, USDA Forest Service, and Dr Walter Mueggler, USDA Forest Service (retired) provided keen insights on aspen ecology and Mr Steve Smith, USDA Forest Service, assisted us greatly in locating study sites.

\section{LITERATURE CITED}

Bartos, D. L. 2001. Landscape dynamics of aspen and conifer forests. In: Proceedings of the symposium on sustaining aspen in western landscapes; 13-15 June 2000; Grand Junction, C0, USA. Ft. Collins, CO, USA: US Department of Agriculture, Forest Service, Rocky Mountain Research Station RMRS-P-18. p. 5-14.

Bartos, D. L., and R. B. Campbell. 1998. Water depletion and other ecosystems values forfeited when conifer forests displace aspen communities. In: D. F. Potts [ED.]. Rangeland management and water resources. Proceedings of American Water Resources Association Specialty Conference; 27-29 May 1998; Reno, NV, USA. Herndon, VA, USA: American Water Resources Association TPS-98-1. p. 427-434.

Betters, D. R. 1983. Overstory-understory relationships: aspen forests. In: E. T. Bartlett and D. R. Betters [EDS.]. Overstory-understory relationships in western forests. Western Regional Research Publication No. 1. Fort Collins, CO, USA: Colorado State University. p. 5-8.

Cook, C. W., AND J. StUBBendieCK. 1986. Methods of studying vegetation. In: Range research: basic problems and techniques. Denver, CO, USA: Society for Range Management. p. 51-81.
Debyle, N. V. 1985. Water and watershed. In: N. V. Debyle and R. P. Winokur [EDS.]. Aspen: ecology and management in the western United States. Ft. Collins, CO, USA: US Department of Agriculture, Forest Service, General Technical Report RM-119. p. 153-160.

Ffolılott, P. F. 1983. Overstory-understory relationships: southwestern ponderosa pine forests. In: E. T. Bartlett and D. R. Betters [EDs.]. Overstoryunderstory relationships in western forests. Western Regional Research Publication No. 1. Fort Collins, C0, USA: Colorado State University. p. 13-18.

FISHER, R. F., AND D. BINKLEY. 2000. Physical properties of forest soils. In: R. Young [ED.]. Ecology and management of forest soils. New York, NY, USA: John Wiley and Sons. p. 61-86.

JAMESON, D. A. 1967. The relationship of tree overstory and herbaceous understory vegetation. Journal of Range Management 20:247-249.

KIRMSE, R. D., AND B. E. NoRTon. 1985. Comparison of the reference unit method and dimensional analysis methods for two large shrubby species in the Caatinga woodlands. Journal of Range Management 38:425-428.

Lambers, H., F. S. Chapin III, and T. L. Pons. 1998. Response of photosynthesis to light. In: Plant physiological ecology. New York, NY, USA: Springer. p. 25-46.

Milliken, G. A., and D. E. Johnson. 2002. Analysis of messy data. Volume III: analysis of covariance. New York, NY, USA: Chapman and Hall/CRC. 452 p.

Morrison, R. G., and G. A. Yarranton. 1970. An instrument for rapid and precise point sampling of vegetation. Canadian Journal of Botany 48:293-297.

Mueggler, W. F. 1985. Forage. In: N. V. Debyle and R. P. Winokur [eds.]. Aspen ecology and management in the western United States. Ft. Collins, CO, USA: US Department of Agriculture, Forest Service, General Technical Report RM119. p. $129-134$.

MueggleR, W. F. 1988. Aspen community types of the intermountain region. General Technical Report INT-250. Ft. Collins, CO, USA: US Department of Agriculture, Forest Service Intermountain Research Station. 135 p.

OHMS, S. R. 2003. Restoration of aspen in different stages of mortality in southern Utah [thesis]. Logan, UT, USA: Utah State University. 99 p.

Pechanec, J. F., and G. D. Pickford. 1937. A weight estimate method for the determination of range or pasture production. Journal of the American Society of Agronomy 29:894-905.

Pyke, D. A., And B. A. Zamora. 1982. Relationships between overstory structure and understory production in the grand fir/myrtle boxwood habitat type of north central Idaho. Journal of Range Management 35:769-773.

SAS InSTITUTE InC [computer program]. 1999. Version 8.2. Cary, NC, USA: SAS Institute.

Stam, B. R. 2004. Quantifying losses of understory forage in aspen stands on the Dixie and Fishlake national forests [thesis]. Logan, UT, USA: Utah State University. $36 \mathrm{p}$.

Utah Snotel. 2003. Utah Snotel sites. Available at: www.wcc.nrcs.usda.gov/snotel/ Utah/utah.html. Accessed 3 December 2003.

Warner, J. A., AND K. T. Harper. 1972. Understory characteristics related to site quality for aspen in Utah. Science Bulletin, Biology Series 16:2. 